\title{
Transesophageal Echocardiography in Ross Procedure
}

\author{
Marcello Fonseca Salgado Filho ${ }^{1}$, Arthur Siciliano ${ }^{2}$, Luiz Antônio Diego, TSA ${ }^{3}$, Leonardo Augusto Miana ${ }^{4}$, \\ Júlia Salgado ${ }^{5}$
}

Summary: Salgado Filho MS, Siciliano A, Diego LA, Miana LA, Salgado J - Transesophageal Echocardiography in Ross Procedure.

Background and objectives: Ross procedure is one of the surgical procedures for correction of severe congenital aortic insufficiency. Intraoperative transesophageal echocardiography is essential for optimal surgical evaluation. Furthermore, it is able to assess the blood volume profile and the need for administration of vasoactive drugs during surgery.

Case report: This is a 15-year old teenager with severe congenital aortic insufficiency scheduled for corrective surgery with the Ross procedure. In the operating room, the patient was monitored with electrocardiography and pulse oximeter, and he was premedicated with midazolam. After the administration of premedication, the left radial artery and right subclavian vein were punctured. Anesthetic induction was accomplished with etomidate, cisatracurium, and fentanyl while maintenance was achieved with sevoflurane. The probe of the transesophageal echocardiography equipment was introduced immediately after tracheal intubation, showing increased left ventricle; severe aortic insufficiency due to coaptation failure of the three leaflets; and competent pulmonary valve without anatomical and physiological changes. Intercurrences were not observed during surgery, with 120 minutes of extracorporeal circulation (ECC) and 8 hours of surgery. Immediately after removal from ECC the transesophageal echocardiography showed good function of both the auto- and homograft; however, the right ventricle presented hypocontractility, which was corrected with a bolus of milrinone followed by continuous infusion. The patient was transferred to the postanesthetic recovery unit intubated and hemodynamically stable with infusion of milrinone and sodium nitroprusside.

Conclusions: Ross procedure is one of the techniques for correction of congenital aortic insufficiency in which transesophageal echocardiography guides the surgeon precisely on the physiological and anatomical status of vascular grafts.

Keywords: Echocardiography, Transesophageal; Aortic Valve Insufficiency; Heart Defects, Congenital; Cardiac Surgical Procedures.

[Rev Bras Anestesiol 2011;61(3): 344-350] @Elsevier Editora Ltda.

\section{INTRODUCTION}

Ross procedure was first described in 1962 when Sir Donald Ross replaced the aortic valve by a homograft ${ }^{1}$, which showed great advantage when compared to the placement of aortic prostheses, such as a decreased incidence of endocarditis, need of anticoagulation, and better hemodynamic profile ${ }^{2}$.

The American Heart Association (AHA), along with the American College of Cardiology (ACC), classifies the use of transesophageal echocardiography (TEE) in surgery for congenital heart disease as Class I, i.e., both societies consider

Received from Instituto Nacional de Cardiologia/Ministério da Saúde, RJ, Brazil.

1. M. D. in Health from Universidade Federal de Juiz de Fora (UFJF); Anesthesiologist of Instituto Nacional de Cardiologia/MS, Professor of Anesthesiology of UNIPAC-JF

2. MBA in Hospital Management; Chief of the Departamento de Anestesiologia of Instituto

Nacional de Cardiologia/Ministério da Saúde

3. Anesthesiologist, TSA/SBA; Chief of Residency of INC/MS, Professor of UFF/RJ

4. PhD in Cardiac Surgery; Cardiac Surgeon of Instituto Nacional de Cardiologia/MS, Pro-

fessor of UFJF

5. Undergraduate Medical Student at UFRJ

Submitted on July 25, 2010.

Approved on December 13, 2010.

Correspondence to:

Dr. Marcello Fonseca Salgado Filho

Rua Alexandre Visentin, 100

Jardim do Sol

36061530 - Juiz de Fora, MG, Brazil

E-mail: mfonsecasalgado@ hotmail.com that the use of TEE in this type of surgery makes a difference on patient prognosis ${ }^{3}$.

Through analysis of transvalvular blood flow, TEE can calculate the viability of the autograft and therefore ensures the surgeon about performing the Ross procedure. Furthermore, TEE helps calculate the volume status, cardiac output, and ventricular function, which are very important during the process of removing the patient from extracorporeal circulation $(\mathrm{ECC})^{5}$.

The objective of this case report was to demonstrate the importance of TEE in heart surgery, especially the Ross procedure.

\section{CASE REPORT}

This is a 15-year-old male patient weighing $50 \mathrm{~kg}, 160 \mathrm{~cm}$, physical status ASA III, and Class III by the NYHA criteria, who presented severe congenital aortic insufficiency, scheduled for surgical treatment with the Ross procedure ${ }^{1}$.

During the pre-anesthetic evaluation, performed in the outpatient clinic two days before the procedure, the anesthetic procedures as well as any possible anesthetic risks were explained to the patient; he also signed an informed consent.

In the operating room the patient was monitored with electrocardiography on two derivations $\left(D_{\|}\right.$and $\left.V_{5}\right)$, analysis of the ST segment, pulse oximeter, bispectral index (BIS) (Datex-Ohmeda ${ }^{\circledR} \mathrm{S} / 5$ Aespire Anesthesia Machine; Helsinki, 
Finland, 2006). The patient was premedicated with midazolam $0.05 \mathrm{mg} \cdot \mathrm{kg}^{-1}$. After premedication, the left radial artery was punctured followed by anesthetic induction with etomidate $0.3 \mathrm{mg} \cdot \mathrm{kg}^{-1}$, cisatracurium $0.2 \mathrm{mg} \cdot \mathrm{kg}^{-1}$, and fentanyl $7 \mu \mathrm{g}$. $\mathrm{kg}^{-1}$. Five minutes after anesthetic induction, a 7.0 ET tube with balloon was introduced, and the right subclavian vein was punctured with a double lumen catheter with the Seldinger technique. Anesthesia was maintained with fentanyl $5 \mu \mathrm{g} \cdot \mathrm{kg}^{-1}$, cisatracurium $2 \mu \mathrm{g} \cdot \mathrm{kg}^{-1} \cdot \mathrm{min}^{-1}$, and sevoflurane up to $2 \mathrm{MAC}$, maintaining the BIS between 40 and 60 .

After tracheal intubation, a \#18 orogastric tube was inserted to empty the stomach, and the oropharynx was lubricated with gel (Savage Laboratory ${ }^{\odot}, \mathrm{NY}$ ) for TEE probe introduction. TEE probe (Vivid ${ }^{\odot}$, Philips, Finland, 2008) was introduced in the esophagus and the exam was initiated with twenty cuts, as recommended by the Society of Cardiovascular Anesthesiologists ${ }^{6}$. It showed increased left ventricle (Figure 1); severe aortic insufficiency due to noncoaptation of the three valve leaflets (Figures 2, 3, 4); mini-



Figure 1 - Four-chamber View through the Middle Esophagus Showing Increased Left Ventricle. VD: Right Ventricle, AE: Left Atrium, VE: Left Ventricle.

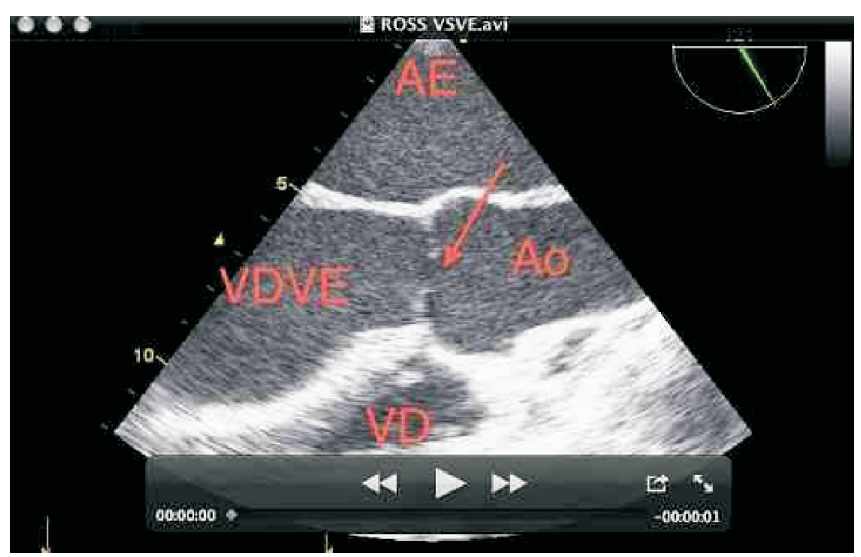

Figure 3 - Long-axis View of the Aortic Valve through the Middle Esophagus. The arrow shows failure of coaptation of aortic valve leaflets. Ao: Ascending aorta, VDVE: Left Ventricular Outlet, AE: Left Atrium, VD: Right Ventricle. mal mitral insufficiency; competent pulmonary valve without anatomic and physiologic changes (Figure 5), which made the Ross procedure viable; and a left ventricular ejection fraction of $60 \%$.

Intercurrences were not observed during surgery. The aortic valve was replaced by a pulmonary autograft and a homograft was placed in the pulmonary site. Extracorporeal circulation (ECC) lasted 120 minutes and the surgery 8 hours. Immediately after removal from ECC, the transesophageal echocardiography showed good autograft (Figure 6) and homograft functioning, with aortic and pulmonary transvalvular gradients within normal limits.

The right ventricle, however, showed hypocontractility, distension, and the tricuspid valve showed minimal to moderate regurgitation. Due to these echocardiographic findings a bolus of milrinone (50 $\mathrm{gg}_{\mathrm{kg}} \mathrm{kg}^{-1}$ during 20 minutes) followed by continuous infusion of $0.5 \mu \mathrm{g} \cdot \mathrm{kg}^{-1} \cdot \mathrm{min}^{-1}$ was administered, which improved the right ventricular function and lead to the disappearance of the tricuspid insufficiency.

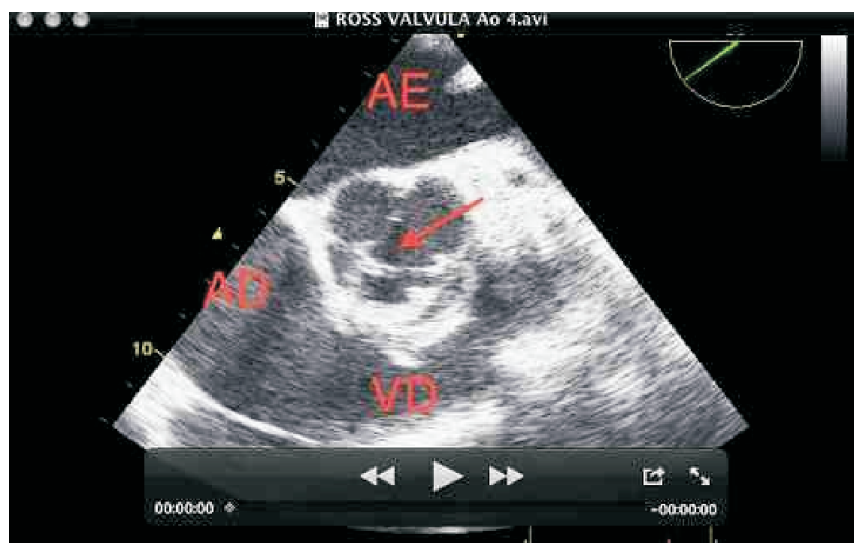

Figure 2 - Short-axis View of the Aortic Valve and Right Ventricular Inlet and Outlet through the Upper Esophagus. The arrow shows the coaptation failure of the three aortic valve leaflets. VD: Right Ventricle, AD: Right Atrium, AE: Left Atrium.

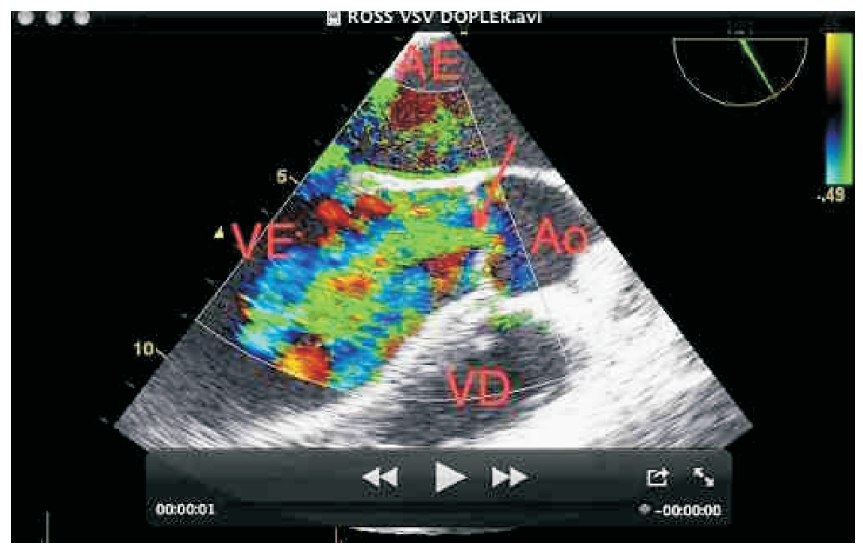

Figure 4 - Long-axis View of the Aortic Valve through the Middle Esophagus. The arrow shows regurgitation through the aortic valve, surpassing the anterior leaflet of mitral valve. Ao: Ascending aorta, VDVE: Left Ventricular Outlet, AE: Left Atrium, VD: Right Ventricle. 


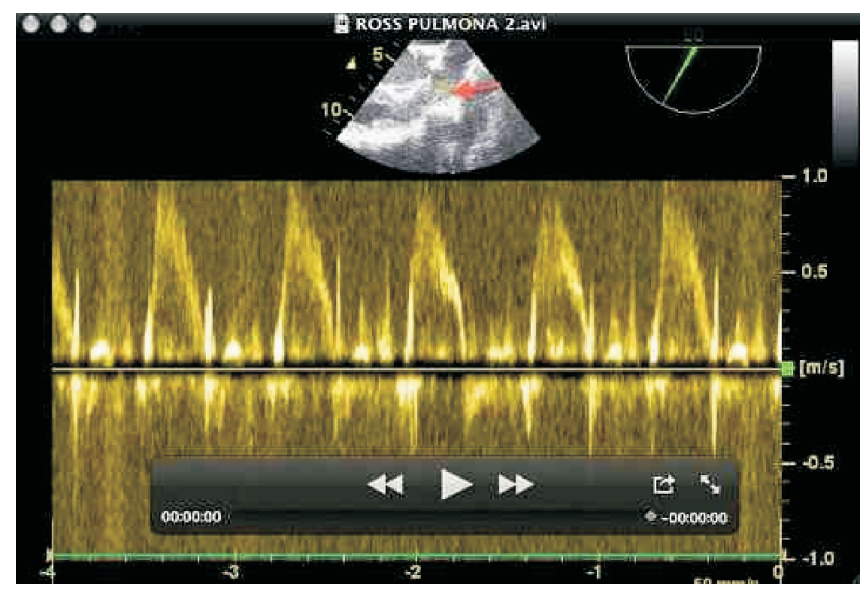

Figure 5 - Short-axis View of the Aortic Valve and Right Ventricular Inlet and Outlet through the Upper Esophagus. The arrow shows the pulsatile Doppler of the pulmonary valve.

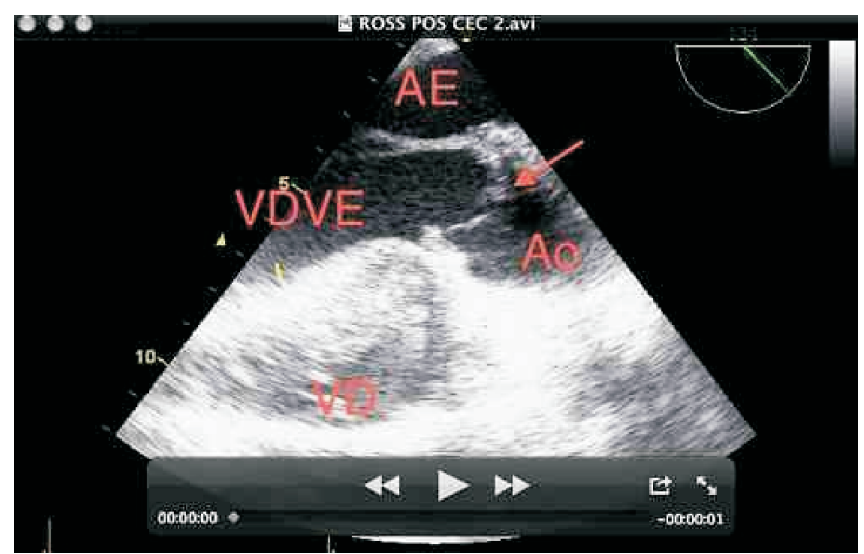

Figure 6 - Long Axis View of the Aortic Valve through the Middle Esophagus. The arrow shows the pulmonary autograft replacing the aortic valve. VD: Right Ventricle, Ao: Ascending aorta, VDVE: Left Ventricular outlet, AE: Left Atrium.

The patient was transferred to the post-anesthetic recovery room intubated, hemodynamically stable, with infusion of milrinone $\left(0.5 \mu \mathrm{g} \cdot \mathrm{kg}^{-1} \cdot \mathrm{min}^{-1}\right)$ and sodium nitroprusside $\left(2 \mu \mathrm{g} \cdot \mathrm{kg}^{-1} \cdot \mathrm{min}^{-1}\right)$. In the first 4 postoperative hours, any important bleeding was not observed; arterial blood gases were within normal limits; and hemodynamic and respiratory parameters showed favorable conditions for extubation, which was performed without intercurrences.

The patient was transferred to regular ward on the fourth postoperative day and discharged from hospital in two weeks.

\section{DISCUSSION}

Transesophageal echocardiography has been used in large centers in the United States as routine monitoring in heart surgeries ${ }^{7}$. Morewood et al. ${ }^{8}$ demonstrated in their study that $94 \%$ of anesthesiologists of the Society of Cardiovascular An- esthesiologists who live in the United States use TEE in heart surgeries.

Intraoperative echocardiography is widely used in cardiac surgeries, since it guides intraoperative management and provides better patient evolution ${ }^{7}$. However, Clirk et al. ${ }^{9}$ questioned the use of TEE in all heart surgeries.

The American Heart Association, along with ACC, established guidelines for the use of TEE in surgical procedures classifying them in conditions in which there is evidence that it is useful and effective (Class I); conditions with conflicting evidence on the usefulness and/or efficacy of the procedure (Class II); conditions in which evidence demonstrate that the procedure is not useful and/or effective and in some cases it might carry complications for patients (Class III) ${ }^{3}$.

In cases of surgery for congenital heart disease with extracorporeal circulation, the AHA/ACC classifies the use of TEE as Class I ${ }^{3}$. Stevenon et al. ${ }^{10}$ demonstrated that among congenital disorders Ross procedure is one of the techniques that need the most evaluation with intraoperative TEE.

In the case presented here TEE was very important in the pre-ECC evaluation of the aortic valve since it confirmed the diagnosis of severe aortic insufficiency besides ensuring the anatomic mechanism of regurgitation.

The study of the pulmonary valve is very important in this case, since the pulmonary valve is used as autograft in the aortic site ${ }^{1}$. The Doppler showed the absence of pulmonary regurgitation and that the gradient was within normal limits ${ }^{4}$. Thus, the surgeon had assurance to continue with the procedure.

Transesophageal echocardiography is important when the patient is taken out of ECC because, at that moment, hemodynamic instability due to the presence of air in cardiac cavities and some degree of myocardial dysfunction produced by a down regulation of beta-adrenergic receptors can be seen ${ }^{11}$. When the patient's ventricular function was analyzed, good function of the left ventricle was observed 5; however, the right ventricle was hypocontractile, distended, and it showed minimal to moderate tricuspid regurgitation ${ }^{4}$, which was not present at the pre-ECC exam. Given these echocardiographic results, treatment with the phosphodiesterase III ${ }^{11}$ inhibitor was instituted and the patient showed improvement of right ventricular contractility, and the tricuspid insufficiency disappeared 4,5 .

Transesophageal echocardiography also allowed confirmation of proper placement of the autograft and homograft and measurement of transvalvular gradients ${ }^{4,10}$, which were within normal limits.

Thus, we can conclude that the use of TEE in the Ross procedure is very important because it guides the surgeon on the possibility of performing the proposed procedure and it helps the anesthesiologist to precisely evaluate myocardial function and the physiological and anatomical status of vascular grafts, providing better precision in the choice of drug therapy to be adopted, ensuring greater patient safety. 


\section{REFERÊNCIAS / REFERENCES}

01. Ross DN - Homograft replacement of the aortic valve. Lancet, 1962;2:487.

02. Barratt-Boyes BG, Roche AH, Brandt PW et al. - Aortic homograft valve replacement. A long-term follow-up of an initial series of 101 patients. Circulation, 1969;40:763-775.

03. Cheitlin MD, Armstrong WF, Aurigemma GP et al. - ACC/AHA/ASE 2003 guideline update for the clinical application of echocardiography. J Am Coll Cardiol, 2003;42:954-970.

04. Nagueh SF - Assessment of valvular regurgitation with Doppler echocardiography. Cardiol Clin, 1998;16:405-419.

05. Thys DM, Hillel Z, Goldman ME et al. - A comparison of hemodynamic indices derived by invasive monitoring and two - dimensional echocardiography. Anesthesiology, 1987;67:630-634.

06. Shanewise JS, Cheung AT, Aranson $S$ et al. - ASE/SCA guidelines for performing a comprehensive intraoperative multiplane transesophageal echocardiography examination: recommendations of the American Society of Echocardiography Council for intraoperative echocardiography and the Society of Cardiovascular Anesthesiologist Task Force for Certification in perioperative transesophageal Ecocardiography. Anesth Analg, 1999;89:870-884

07. Thys DM - Echocardiography an anesthesiology successes and challenges. Anesthesiology, 2001;95:1313-1314.

08. Morewood GH, Gallangher ME, Gaughan JP et al. - Current practice patterns for adult perioperative transesophageal ecocardiography in the United States. Anesthesiology, 2001;95:1507-1512.

09. Click RL, Abel MD, Schaff HV - Intraoperative transesophageal echocardiography: 5-year prospective review of impact on surgical management. Mayo Clin Proc, 2007;75:241-247.

10. Stevenson JG, Sorensen GK, Gartman DM et al. - Transesophageal echocardiography during repair of congenital defects: identification or residual problems necessitating reoperation. J Am Soc Echocardiog, 1993;6:356-365.

11. Griffin MJ, Hines RL - Management of perioperative ventricular dysfunction. J Cardiothorac Vasc Anesth, 2001;15:90-106.
Resumen: Salgado Filho MS, Siciliano A, Diego LA, Miana LA, Salgado J - El Ecocardiograma Transesofágico en la Cirugía de Ross.

Justificativa y objetivos: Una de las cirugías correctivas para la insuficiencia aórtica congénita grave es la cirugía de Ross. El ecocardiograma transesofágico intraoperatorio es indispensable para una buena evaluación quirúrgica. Además, es capaz de evaluar el perfil volémico y la necesidad de administrar fármacos vasoactivos durante la operación.

Relato del caso: Adolescente de 15 años, que presentaba insuficiencia aórtica grave de origen congénito, citado para la corrección quirúrgica por la técnica de Ross. En quirófano, el paciente fue monitorizado con electrocardiograma y oxímetro de pulso, recibiendo premedicación con midazolan. Después de la premedicación, se puncionaron la arteria radial izquierda y la vena subclavia derecha. La inducción anestésica se hizo con etomidato, cisatracurio y fentanil, y el mantenimiento anestésico con sevoflurano. La sonda del aparato del ecocardiograma transesofágico fue introducida inmediatamente después de la intubación traqueal e indicaba aumento del ventrículo izquierdo; insuficiencia aórtica grave por falla de coaptación de las tres capas; válvula pulmonar competente sin alteraciones anatómicas y fisiológicas. La cirugía trascurrió sin intercurrencias, con 120 minutos de circulación extracorpórea (CEC), y 8 horas de cirugía. Inmediatamente después de la salida de CEC, el ecocardiograma transesofágico mostraba un buen funcionamiento tanto del auto como del homoinjerto, sin embargo, el ventrículo derecho estaba hipocontráctil, lo que fue corregido con un bolo de milrinona, seguido de infusión continua. El paciente fue derivado al postoperatorio intubado, estable hemodinámicamente, y con infusión de milrinona y nitroprusiato de sodio.

Conclusiones: Una de las técnicas de corrección de la insuficiencia aórtica congénita es la cirugía de Ross, en que el ecocardiograma transesofágico intraoperatorio orienta al cirujano de manera precisa sobre el status fisiológico y anatómico de los injertos vasculares.

Descriptores: CIRUGÍA, Cardíaca; EFERMEDAD, Congénita: insuficiencia aórtica; MONITORIZACIÓN: ecocardiografía transesofágica. 